\title{
Pedagogical Insights into the Use of Minecraft within Educational Settings
}

\author{
Gisli THORSTEINSSON ${ }^{1}$, Andrei NICULESCU ${ }^{2,3}$ \\ ${ }^{1}$ University of Iceland, \\ v/Stakkahlid, 101, Reykjavik, Iceland. \\ cdt@hi.is \\ ${ }^{2}$ Spiru Haret University, \\ 13 Ion Ghica Street, Bucharest 3, Romania \\ andreiniculescu@hotmail.com. \\ ${ }^{3}$ National Institute for R \& D in Informatics, \\ 8-10 Averescu Blvd. 011455 Bucharest 1, Romania,
}

\begin{abstract}
This article highlights a research study that examined teachers' and students' work utilising the popular PC game Minecraft within an educational setting. The main purpose of the study was to give insights into the pedagogy of using Minecraft within such a context. Interviews were undertaken with practicing teachers, observations were carried out and related documents were analysed. The data produced was qualitative, while the analysis was based on grounded theory principles and an interpretive paradigm. The key issues under consideration in the research were the following: a) the role of teachers in this game-driven educational context, b) the extent to which the Minecraft software affects students' learning practices and c) how the teachers' pedagogy could be enhanced. The study revealed both pedagogical benefits and drawbacks. The findings from this study suggest that students were mostly motivated to use Minecraft in its creative mode that enhanced learners' problem solving skills and helped them to reach a compromise. The high creative potential of Minecraft also offered teachers a broad range of possibilities to assign interdisciplinary project-based collaborative tasks.
\end{abstract}

Keywords: Minecraft, gamification learning, education, pedagogy, research, teachers and students.

\section{Introduction}

Using desktop-based virtual reality technologies (DVRT) is an integral part of young people's daily lives and such games can be both entertaining and educational. The use of computer games within education is often referred to as gamification of learning. Gamification of learning (GL) is an educational approach that motivates students by using gamebased elements within educational settings (Kapp, 2012; Shatz, 2015). The aim is to capture students' interest and motivate them to learn (Burke, 2014). Using DVRT for Game Based Virtual Learning (GBVL) is an ideal mode of supporting students' learning, as it enables communication and the collation of information in an enjoyable manner (Hennessey \& Deaney, 2004; Passey et al., 2004).

Research findings from the OECD (OECD, 2015) indicate that, although most students have access to computers and the Internet, they do not necessarily know how to utilise them in the learning process. It was also shown that there has been no considerable progress in student knowledge and skills in reading, mathematics or science in countries that have largely invested in traditional ICT opportunities for education. Thus, schools must find new ways to educate young students using ICT opportunities, in order to prepare them for an interconnected existence where they will have to live and work with individuals from different nations and dissimilar cultural backgrounds (Thorsteinsson, Page and Niculescu, 2012).

Decades of research within the field of ICT-use within education indicate that educators are at a very early stage of such usage. The OECD (OECD, 2015) asserted that the use of ICT to enhance learning requires a broader strategy in terms of skills and fresh opportunities, such as the use of Game Based Virtual Learning Environments (GBVLE). It is therefore important to look in more depth at the complex and diverse reality of young students' digital literacy practices, in order to be able to better 
evaluate the skills, knowledge and general understanding that students require in order to benefit from the use of ICT within educational settings. Schools must cultivate broader ICT skills among students in order to support conventional education and to allow for the opportunity of increased creativity within schools. Gamification learning could be utilised across all lessons (Zichermann, 2010).

Gamification literature has been growing and commercial enterprises have been developing the actual elements of gamification in order to increase consumer involvement, inspiration and productivity. However, educators have been slow to recognise the benefits of gamification through the use of GBVLEs (McGonigal, 2010; Thorsteinsson and Niculescu, 2013).

The paper is organized as follows: An overview of relevant literature pertaining to the use of ICT in education and gamification learning in GBVLEs is given at the beginning of the paper. The authors then outline the research methodology before discussing the findings and drawing conclusions.

\section{Using ICT within Education}

ICT is based on computer technologies that enable communication and ensure that information is easily accessible. ICT in schools is based on the use of various software applications and an Internet connection, in order to enable students' learning (Hall, 2001; Paulsen, 2003; Thorsteinsson et al., 2007; Thorsteinsson and Niculescu, 2013; Thorsteinsson, Gunnarsdottir and Niculescu, 2015).

The use of computers in schools is complex, due to rapid technological changes within IT industry. However, Taylor (1980) and Blom and Monk (2003) argued that teachers and students require little knowledge of computers when they are used as tutors and tools to enhance learning. Blom and Monk (2003) outlined the role of computers in education as below:

1. Tutor (computer-aided instructor): students are given information and are later tested on this.

2. Tool: students lead the learning process as an active process of constructing knowledge through practise.
3. Tutee: students use construction kits that help them to reflect upon what they have learned.

4. Enabling computer supported collaborative learning: students learn from utilising network connected software to communicate with teachers or co-students in different locations.

Conversely, a positive attitude towards technology does not ensure that teachers will be able to utilise such technology effectively within the classroom. Teachers are prevented from using new technology in multifarious ways; for example, they are under strict time constraints both inside and outside the classroom (Lam, 2000; Levy, 1997; Reed et al., 1995; Smerdon et al., 2000; Strudler, Quinn, McKinney \& Jones, 1995) and they do not have enough resources (Loehr, 1996; Smerdon et al, 2000). Teachers also lack sufficient guidelines (Worthington, 2008; Langone et al., 1998), support and recognition for incorporating ICT within their classes (Grau 1996; Strudler, McKinney \& Jones, 1999). Recently-graduated teachers often experience difficulties in introducing new approaches in older schools (Smerdon et al., 2000) with a conservative culture (Ertmer, 1999) and do not receive sufficient technical support or training (AbdalHaqq, 1995; Lam, 2000; Langone et al., 1998; Levy, 1997a; Smerdon et al., 2000). Levy (1997) suggested that fast developing computer technology poses a hindrance to those who use it. Furthermore, curricular restrictions may limit teachers' ability to utilise such technology (Egbert, Paulus \& Nakamichi, 2002).

\section{Game Based Virtual Reality Learning (GBVRL)}

Presently, the use of GBVLEs in education is viewed in a rather cynical manner. Various research studies have indicated that, although approximately $90 \%$ of students play video games outside of school (Paglia-Boak, 2012), many qualified teachers have a negative view of the use of GBVLEs within the classroom and believe that these would distract students rather than support them (Baek, 2008).

GBVLE (gamification) may be defined as the use of elements of game design within nongaming settings (Oxford Dictionaries, 2016). 
The GBVLE utilises games that induce learning (Werbach and Hunter, 2012) and refers to the method of defining elements that form a game and make it enjoyable, in order to motivate players to play it within a non-gaming context and to influence their activities (Huotari \& Hamari, 2004). Within educational settings, examples of positive student behaviour and motivation as a result of the use of GBVLEs are finding meaning in learning tasks and displaying initiative in the classroom.

The GBVLE enables the creation of a learner's world, with the freedom to analyse, plan and experience, and GBVLEs can be utilised in learning in two ways. Firstly, the use of gamebased elements within a nongaming setting acts as a stimulus in motivating students to take part. Secondly, computer games can be used to highlight the methodologies and educational outcomes of GBVLEs (Zichermann, 2010). According to Teed (2016), there are several elements that define an activity as a game:

1. Competition: winning conditions that encourage players and assess their performance

2. Engagement: students become engaged and do not lose focus until the game is over. This is the student's intrinsic motivation and includes challenge, curiosity, control and fantasy.

3. Immediate Rewards: students are thrilled if they win and thus often want to play the game again.

\section{Minecraft}

Minecraft was created in 2009 and is a popular PC game amongst young students. It is an indie game, with over 24 million registered users (Minecraft.net, 2016). Minecraft is based on the iconic Lego game idea, but takes place within a virtual world. The game is based on the socalled sandbox construction system, which gives the gamer freedom to move around inside an unlimited virtual reality world (Bebbington and Vellino, 2015).

Inside of the virtual gaming world, students can construct using different blocks, such as stone blocks, wooden blocks and dirt stone. The blocks are used to modify the environment; i.e., by building houses, aeroplanes, boats, bridges, etc. (Minecraft.net, 2016). The game can be played both online and offline or in a local network. There are three different game modes in Minecraft, of differing natures:

1. Creative: unlimited resources, free flying and destroying blocks instantly.

2. Survival: search for resources, crafting, gain levels, health and hunger.

3. Hard-core: same as survival mode, locked at hardest difficulty and one life only.

With regards to the basic elements of the software, there are four special features:

1. The Minecraft game has no obvious goal and can therefore last forever.

2. The graphics are based on simple 8-bit graphics.

3. Minecraft inspires users to explore and construct.

4. As the game is a multiplayer virtual world, players can collaborate online in real time.

Minecraft has been used by numerous teachers as an extra activity within conventional classes, most often using a constructivist approach. According to Gee (2007) and Squire (2011), quality videogames and their developing cultures offer problemsolving spaces where learning take place, since challenge and learning is at the centre of motivation and entertaining.

Minecraft is suitable in the teaching of many subjects, such as science, and offers incorporated electronics and electricity elements (Short, 2012). The software has proven popular in teaching non-scientific subjects in primary and secondary schools and also in higher education. Garcia-Martinez (2014) asserted that, within higher education, Minecraft is used as a learning aid in Computer Art, the Fundamentals of Video Games studies, Digital Storytelling and Writing and Rhetoric for English as a Second Language. However, Minecraft was only used for part of the courses, along with additional tools.

Recently, Minecraft has been utilised to address concerns relating to distance learning within some universities. Livingstone et al. (2013) informed how the University of the West of Scotland considered Minecraft an appropriate teaching tool in online studies featuring classes in different locations. 
Many teachers do not feel adequately prepared for the numerous technological possibilities and constraints offered by using Minecraft software in various tasks and as an extra activity. Ertmer (1999) considered that these limitations were twofold; i.e., external factors, such as lack of computers in schools, and barriers in the teachers' attitudes and beliefs. He concluded in his research that some teachers are naturally wary of technological changes. However, there are numerous technological tools available today and a quick search on the Internet will allow teachers to keep updated on what's new in classroom technology.

\section{Research Methodology}

The main purpose of the research project was to understand the pedagogical nature of teachers' and students' work through the use of Minecraft within educational settings. As the use of VRLE software is a relatively new concept, this needs to be critically examined and its nature evaluated.

Overall Aim: to explicate the pedagogy of the use of Minecraft within educational settings.

The objectives were the following:

1. Developing an understanding of teachers' work relating to the use of Minecraft

2. Identifying significant aspects that affect students' work when using Minecraft

3. Recognising the value of the use of Minecraft within education

The research questions were:

1. What characterises teachers' work in a game-driven educational context?
2. How did students managed to use the Minecraft software in the education settings?

3. How can teachers' work be improved in the context of ICT?

Several collection techniques were used in this study, such as semi-structured interviews, observations and document analysis that helped to validate and cross-check findings. Six semistructured interviews were undertaken with teachers that utilised Minecraft in their classrooms, both as a game and a teaching tool. They had been using Minecraft both as an after class activity or in conventional classrooms to support students' learning inside different subject areas.

The teachers were responsible for instructing students within the ages of 6-11 and most of the students were new to Minecraft. The interviews were conducted via Skype and face to face and were based on a semi-structured interview schedule developed from the literature review including questions about the teachers' preparation, their ICT skills, teacher's role and teaching process handling, his/her preparation, the need for training, difficulties and specific problems, use of the software, learning, motivation, creativity, use of the software, collaboration and values.

The data was analysed via phenomenological analysis (Creswell, 2007), in view of the literature, and placed into major categories. The research was interpretive, as it attempted to realise and interpret the use of the Minecraft software, the teacher's pedagogy and students' learning practices. Neuman (1997: 68) described this as 'exploring socially meaningful actions through the direct detailed observation of people in natural settings in order to arrive at

Table 1. Semi-structured interviews were taken to teachers. This was also supported via specific Icelandic website including teaching plans and ideas (https://minecraftverkefnabok.net/)

\begin{tabular}{|l|l|l|}
\hline Teacher no. 1 & Art and Craft. Designing and building together in a creative mode & 5-7 year old \\
\hline Teacher no. 2 & Geography using a map of Iceland. Exploring and solving tasks & 6-11 year old \\
\hline Teacher no. 3 & Multimedia making from editing screen captured videos & 6-11 year old \\
\hline Teacher no. 4 & Using cad for designing in Minecraft together with 3D printing & 6-11 year old \\
\hline Teacher no. 5 & Mathematics-focusing on cubic and square measures/units & 7-11 year old \\
\hline Teacher no. 6 & $\begin{array}{l}\text { Special teaching e.g. building up speech and language skills along } \\
\text { with Skype }\end{array}$ & 6-10 year old \\
\hline
\end{tabular}


understandings and interpretations of how people create and maintain their social worlds.'

As the research was undertaken in a multifaceted social/educational context, grounded theory principles (Glaser and Strauss, 1967) were used to observe, describe and interpret the data. Important findings were checked with series of codes, which were then collated into conceptual categories. These categories were interrelated as a theoretical clarification of action(s) that resolved participants' core concerns with key areas (Denzin, 1984).

\section{Discussing the Main Research Outcomes}

The teachers in the study utilised the Minecraft software within different subject areas. However, they commonly used the same game design elements in their nongaming classroom settings. The main pedagogical issues that emerged from the data were:

1. Teachers' familiarity with the software

2. The teachers' work using ICT

3. Workload

4. Students' use of the software in the Educational Settings

5. Motivation

6. Collaboration

7. Online ethics and security.

\subsection{Teachers' familiarity with the Minecraft software}

Teachers must be skilled in using the Minecraft software and it is beneficial if they find it enjoyable. It is important for teachers to be familiar with the software and to prepare for lessons by solving tasks they are going to give students. This enables teachers to help students and assist them when they are working inside the Minecraft world. Russell et al. (2003) asserted that teachers need to be competent in using software within school, in order be able to assist a class with wide-ranging capabilities and foster a belief in the use of the technology. Mumtaz (2000) identified reasons why teachers did not incorporate the use of computers in the classroom and these included lack of familiarity with ICT, lack of help in guiding pupils, lack of on-site technology support, not very user-friendly computer programs and a lack of specialist help in the area of ICT.

\subsection{Teachers' work utilising ICT}

Teachers are required to possess miscellaneous competences in the use of ICT, in order to assist their classes within the virtual world. They must also be aware of upgrades and software changes and be able to install these on computers. Students are at different levels of competency, depending on their prior ICT experience; thus, teachers must switch between being tutors and facilitators or supervisors with a general knowledge of ICT and they must also be able to support students in their studies (Thorsteinsson and Niculescu, 2013). Obviously, this creates extra workload for teachers. As a result, some teachers appointed older, more skilled students to assist them in guiding younger students, with great success, as it made their work easier. Walker (2000) and Witfelt (2000) acknowledged the complex multiple roles and duties of teachers in the use of ICT within schools. Teachers must constantly upgrade their knowledge and technical skills, in order to ensure that students' learning is authentic and appropriate. Also, when utilising online software within a conventional classroom, the instructor has to use multiple teaching methods, which makes their work multifaceted (Thorsteinsson and Niculescu, 2013; Worthington, 2008). Furthermore, the focus moves from instructional teaching methods to supporting students' independent studies (Matthiasdottir, 2001).

\subsection{Workload}

Teachers considered computer-related work as an extra workload, in addition to their conventional teaching. They found themselves both in a role of instructor and computer administrator. Manternach-Wigans (1999) argued in his research that teachers are sometimes unable to use ICT because they lack the time to prepare for lessons (Fabry \& Higgs, 1997; Preston et al., 2000). Johannsdottir (2008) informed that teachers require ongoing support and guidance, particularly with regards to new technologies in schools. Teachers must also be able to constantly adapt to new circumstances and must learn to develop the curriculum accordingly. 


\subsection{Students' use of Minecraft in the educational settings}

Students often forgot their login username and password for Minecraft and their accounts were blocked if they logged in too many times using the wrong details. The teachers often had to help them to log onto the system. However, use of the software increased students' computer literacy and their capability in using it. Initially, students often had difficulties using the mouse and the keyboard together, when navigating inside the virtual world. It also took time for them to learn crafting or to make things, such as weapons, from different materials. However, the more skilled students became in using the software and the computer, the better they were able to express themselves in a creative manner. Students were most attracted to the creative mode of the software, which presented teachers with many possibilities for projects based on collaborative tasks; in addition, the software enhanced creative thinking. In general, students were able to build creatively in Minecraft. It was important that students were given tasks in accordance with their skill level rather than their age.

\subsection{Motivation}

To get students motivated and make the school activities homelike when using Minecraft was important for the teachers. One of the teachers stated: "The students have to think it is fun and otherwise what is the point? There are plenty of educational games out there and frankly speaking very few of them have ever been satisfying for me. I never wanted to use them in my classroom as it's smells like school." Students were mostly motivated to use Minecraft in its creative mode, as it gave them the freedom to solve tasks in a more personal manner. As students became more skilled, their motivation became stronger. Their interest increased further if they were allowed to assist beginners in a class, upon having gained the relevant skills. Many finished learning tasks at home and, once they learned to create a local server, they could show their family their work. Sometimes students made online friends through Minecraft, which also increased their motivation. Research has shown that, in English schools, ICT has a motivational effect on most pupils (Passey et al., 2004). This study was concerned with the rapid growth of ICT in schools and its effectiveness within the context of teaching and learning. One of the findings was that pupils and teachers recognised that some aspects of quality of work are improved when ICT is used. Attitudes towards schoolwork and homework are often more positive and pupil confidence and ability to perform learning tasks is often enhanced. Many studies concerning the use of GBVLEs within the classroom highlight assertions of improved motivation and learning (Ainge, 1996; Bricken \& Byrne, 1993; Johnson, Moher, Choo, Lin \& Kim, 2002).

\subsection{Collaboration}

Some of the teachers used opportunities during lessons to teach students concepts that supported their individual strength and collaborative abilities. As one of the teachers said: "I also teach them meanings of terms I think helps to build up their collaboration as fellowship, colleagueship, companionship, company, interaction, interconnection, dealings, autonomy, independent and joint work and positivism." Most of the students chose to work together in pairs rather than in groups. However, some teachers set tasks for their whole class. Some students experienced conflict as a result of differing opinions, but these were usually able to be solved creatively, such as in creating a form with individual textures. Students often communicated through Minecraft outside school, using Skype for communication whilst playing inside the virtual world. They often worked independently, but collaborated when necessary, using different modes of communication. Within the classroom, students were able to send text messages to show their work to each other or used avatar gestures inside Minecraft. It was found that smaller groups worked better together and were more productive (Hare, 2003).

\subsection{Ethics and security}

Some teachers had established an online server for students for meeting outside school. If this is done, it is important to set up a whitelist with participants' user names, in order to avoid imposters and ensure the online safety of students. It is also necessary to use Minecraft plugins, in order to prevent the use of obscene or offensive language. In addition, teachers 
should login regularly to ensure that students behave in a proper manner. Specific tasks to examine the ethics of the online community may also be allocated to older students. Plugins can be set up to prevent students from destroying constructions or other students' work, which may distract affected students within the virtual world. It has been argued that computer security may undermine rights (Brey, 2007), but whenever teachers work with children online appropriate cyber security exercises should be conducted.

\section{Conclusion}

Teachers need ICT skills to properly use Minecraft and also need to enjoy using it so that they may fully understand students' state of being and be able to create a conducive learning environment. This is a major advantage, as it ensures that such teachers are capable of adequately assisting their students. They must also be aware of solutions to the tasks they assign to their students, based on their own experience of such tasks (Russell et al., 2003; Mumtaz, 2000; Thorsteinsson and Niculescu, 2013).

Teachers believed that training students was beneficial in providing them with knowledge (i.e., placing them in the role of instructor), as was their own personal experiences (facilitator role). The structure of the GBVRLE supported teachers in their role as facilitator, as indicated by Bonk \& Cunningham (1998) and Heinze (2008). Furthermore, it appeared to enable individuality, collaboration and cooperation while supporting students' autonomy. Being in the role of both instructor and computer administrator proved to be an extra workload for teachers, which meant they lacked time for lesson preparation: this made the ICT approach undesirable for many of the teachers (Matthiasdottir, 2001; Johannsdottir, 2008; Fabry \& Higgs, 1997; Preston et al., 2000; Manternach-Wigans, 1999).

Teachers must have various ICT competences and be aware of software upgrades. As a result of students' varying ICT skills, teachers have to utilise multiple teaching methods as tutors and facilitators or supervisors, in order to help students concentrate on their studies (Thorsteinsson and Niculescu, 2013). Teachers must also move away from traditional instructional teaching methods to facilitate students' independence in their studies (Matthiasdottir, 2001). If instructors run their classes in a cooperative manner, students will be intrinsically motivated to help one another during their study sessions (Walker, 2000; Witfel, 2000; Thorsteinsson and Niculescu, 2013; Worthington, 2008).

\section{REFERENCES}

1. ABDAL-HAQQ, I., Infusing Technology into Preservice Teacher Education. ERIC Digest 389699, 1995, pp. 1-6 (available at http://files.eric.ed.gov/fulltext/ED389699.p df accessed on 25.03.2016).

2. AINGE, D. J. Upper Primary Students Constructing and Exploring Three Dimensional Shapes: A Comparison of Virtual Reality with Card Nets. Journal of Educational Computing Research, vol. 14(4), 1996, pp. 345-369.

3. BEBbington, S., A. VEllinO, Can Playing Minecraft Improve Teenagers' Information Literacy? J. of Information Literacy, vol. 9(2), 2015, pp. 6-26.

4. BAEK, Y. K., What Hinders Teachers in Using Computer and Video Games in the Classroom? Exploring Factors Inhibiting the Uptake of Computer and Video Games. Cyber Psychology, Behaviour and Social Networking, vol. 6(1), 2008, pp. 665-71.

5. BLOM, J. O., A. F. MONK, A Theory of Personalisation of Appearance: Why Users Personalise Their PCs and Mobile Phones. Human-Computer Interaction, vol. 18(3), 2003, pp. 193-228.

6. BONK, C. J., D. J. CUNNINGHAM, Chapter 2: Searching for Learnercentred, Constructivist, and Sociocultural Components of Collaborative Educational Learning Tools. In Bonk, C.J. and King, K.S. (Eds.). Electronic collaborators: Learner-centred technologies for literacy, apprenticeship, and discourse, 1998, pp. 25-50. Mahwah, NJ: Erlbaum. 
7. BREY, P., Ethical Aspects of Information Security and Privacy, in: Security, Privacy, and Trust in Modern Data Management. In M. Petković and W. Jonker (Eds.). Heidelberg: Springer, 2007, pp. 21-36.

8. BRICKEN, M., C. M. BYRNE, Summer Students in Virtual Reality: A Pilot Study on Educational Applications of Virtual Reality Technology. In A. Wexelblat (Ed.), Virtual reality applications and explorations. Cambridge, MA: Academic Press Professional, 1993.

9. BURKE, B., Gamify: How Gamification Motivates People to Do Extraordinary Things. Brookline: Bibliomotion, Inc., 2014.

10. CRESWELL, J. W., Qualitative Inquiry and Research Design: Choosing among Five Traditions. Thousand Oaks, CA: Sage, 1998.

11. CRESWELL, J. W., Qualitative Inquiry and Research Design: Choosing among Five Approaches (2nd ed.). Thousand Oaks. CA: Sage, 2007.

12. DENZIN, N. K., The Research Act. Englewood Cliffs, NJ: Prentice Hall, 1984.

13. EGBERT, J., T. PAULUS, Y. NAKAMICHI, The Impact of CALL Instruction on Language Classroom Technology Use: A Foundation for Rethinking CALL Teacher Education? Language Learning \& Technology, vol. 6(3), 2002, pp. 108-126.

14. ERTMER, P. A., Addressing First- and Second-order Barriers to Change: Strategies for Technology Integration. Educational Technology Research and Development, vol. 47(4), 1999, pp. 47-61.

15. FABRY, D., J. HIGGS, Barriers to the Effective Use of Technology in Education. Journal of Educational Computing, vol. 17(4), 1997, pp. 385-395.

16. GEE, J. P., What Video Games Have to Teach Us About Learning and Literacy. Palgrave Macmillan, 2003.
17. GLASER, B. G., A. L. STRAUSS, The Discovery of Grounded Theory: Strategies for Qualitative Research. New York: Aldine Publishing Company, 1967.

18. GRAU, I., Teacher Development in Technology Instruction: Does Computer Coursework Transfer into Actual Teaching Practice? Paper presented at the Annual Meeting of the Southwest Educational Research Association, Dallas, TX, 1996. ERIC Document Reproduction Service No. ED394949.

19. HALL, B., New Technology Definitions, 2001, (available at www.brandonhall.com/ public/glossary/index.htm accessed on 26.07.2016).

20. HARE, P. A., Roles, Relationships, and Groups in Organizations: Some Conclusions and Recommendations. Small group research, vol. 34 (2), 2003.

21. HEINZE, A., Blended Learning: An Interpretive Action Research Study. $\mathrm{PhD}$ Thesis, Salford: University of Salford, 2008.

22. HENNESSEY, S., R. DEANEY, Sustainability and evolution of ICT supported classroom practice, 2004 (available at http://131.111.153.52/istl/ SAE041.doc accessed on 26.07.2016).

23. HUOTARI, K., J. HAMARI, J. Defining Gamification - A Service Marketing Perspective". Proceedings of the 16th International Academic MindTrek Conference 2012, Tampere, Finland, October, 2012, pp. 3-5.

24. JOHANNSDOTTIR, T. J., Áhrif Netsins á menntakerfið. 2008, Retrieved (available at http://ust.khi.is/tjona/ahrifnet.htm accessed on 26.07.2016).

25. JOHNSON, A., T. MOHER, Y. CHOO, Y. J. LIN, J. KIM, J. Augmenting Elementary School Education with VR. IEEE Computer Graphics and Applications, March/April, 2002, pp. 6-9.

26. KAPP, K., The Gamification of Learning and Instruction: Game-based Methods and Strategies for Training and Education. San Francisco: Pfeiffer, 2012. 
27. LAM, Y., Technophilia v. Technophobia: A Preliminary Look at Why Second Language Teachers Do or Do Not Use Technology in Their Classrooms. Canadian Modern Language Review, vol. 56(1), 2000, pp. 389-420.

28. LANGONE, C., C. WISSICK, J. LANGONE, G. ROSS, A Study of Graduates of a Technology Teacher Preparation Program. Journal of Technology and Teacher Education, vol. 6(4), 1998, pp. 283-302.

29. LEVY, M. Computer Assisted Language Learning: Context and Conceptualization. Oxford: Clarendon Press. 1997.

30. LiVInGSTONE, S., M. BUlGER, A Global Agenda for Children's Rights in the Digital Age: Recommendations for Developing UNICEF's Research Strategy. Florence: UNICEF Office of Research, 2013.

31. LOEHR, M., Top Ten Media Competency Recommendations by Teachers for Teacher Training, Technology and Teacher Education Annual, 1996, pp. 474-476.

32. MANTERNACH-WIGANS, Technology Integration in Iowa High Schools: Perceptions of Teachers and Students. Iowa State University, 1999.

33. MATTHIASDOTTIR, A., Kennslurými. UT fyrir framhaldsskóla, 2001, (available at http://www.lara.is/utn/tenglar/ LTilKennara.htm 25.07.2016).

34. MCGONIGAL, Gaming Can Make a Better World. TEd.

35. MINECRAFT.NET. Minecraft. (available at http://www.minecraft.net 25.071.2016).

36. MUMTAZ, S., Factors Affecting Teachers' Use of Information and Communications Technology: A Review of the Literature. Journal of Information Technology for Teacher Education, vol. 9(3), 2000, pp. 319-342.

37. NEUMAN, W. L, Social Research Methods: Qualitative and Quantitative
Approaches. 3rd edition. Boston: Allyn and Bacon, 1997.

38. OECD. Students, Computers and Learning: Making the Connection, PISA. OECD Publishing, (available at http://dx.doi.org/10.1787/9789264239555en, accessed on 25.07.2016).

39. OXFORD DICTIONARIES. (available at http://www.oxforddictionaries.com/definiti on/english/gamification accessed on 25.07.2016).

40. PAGlia-BOAK, A. E. The Mental Health and Well-being on Ontario Students, 1991-2012. Toronto: Centre for Addiction and Mental Health, 2012.

41. PASSEY, D., C. ROGERS, J. MACHELL, G. MCHUGH, The Motivational Effect of ICT on Pupils. Lancaster: Department of Educational Research Lancaster University, 2004.

42. PATTON, M. Q., Qualitative Evaluation and Research Methods (2nd ed.). Newbury Park, CA: Sage, 1990.

43. PAULSEN, M. F., Online Education and Learning Management Systems. Oslo: NKI Forlaget, 2003.

44. PRESTON, C., M. COX, K., COX, Teachers as Innovators: An Evaluation of Teachers' Motivation in the Use of ICT. London: MirandaNet, 2000.

45. REED, W., D. ANDERSON, J. ERVIN, J. OUGHTON, Computers and Teacher Education Students: A Ten Year Analysis. Journal of Computing in Childhood Education, vol. 6(1), 1995, pp. 5-24.

46. RUSSELL, M., D. BEBELL, L., O'DWYER, K. O'CONNOR, Examining Teacher Technology Use: Implications for Pre-service and In-service Teacher Preparation. Journal of Teacher Education, vol. 54 (4), 2003, pp. 297-310.

47. SHATZ, I., Using Gamification and Gaming in Order to Promote Risk Taking in the Language Learning Process, Proceedings of the 13th Annual 
MEITAL National Conference, Haifa, Israel, 2015, pp. 227-232.

48. SHORT, D., Teaching Scientific Concepts Using a Virtual World Minecraft. Teaching Science, vol. 58(3), 2012, pp. 55-58.

49. SMERDON, B., S. CRONEN, L. LANAHAN, J. ANDERSON, N. IANNOTTI, J. ANGELES, Teachers' Tools for the 21st Century: A Report on Teachers' Use of Technology. Washington, DC: National Center for Education Statistics, 2000.

50. SQUIRE, K. Video Games and Learning: Teaching Participatory Culture in the Digital Age (Technology, Education - Connections. Teachers' College Press, 2011.

51. STRUDLER, N., M. MCKINNEY, W. JONES, First-year Teachers' Use of Technology: Preparation, Expectations and Realities. Journal of Technology and Teacher Education, vol. 7(2), 1999, pp. 115-129.

52. STRUDLER, N., L. QUINN, M. MCKINNEY, W. JONES, From Coursework to the Teal World: First-year Teachers and Technology. In D. A. Willis, B. Robin, \& J. Willis (Eds.), Technology and Teacher Education Annual, Charlottesville, VA: AACE, 1995, pp. 774-777.

53. TAYLOR, R., The Computer in the School: Tutor, Tool, Tutee. New York: Teachers College Press, 1980.

54. TEED, R., How to Teach Using GameBased Learning. In Game-Based Learning, 2016, (available at http://serc.carleton.edu/introgeo/games/ind ex.html accessed on 25.06.2015).

55. THORSTEINSSON, G., A. NICULESCU, Using Mobile Technology for Problem Need Identification in School-aged Children Environment. Studies in Informatics and Control, vol. 21(4), 2012, pp. 431-438.
56. THORSTEINSSON, G., A. NICULESCU, Examining Teachers' Mindset and Responsibilities in Using ICT, Studies in Informatics and Control, vol. 22(3), 2013, pp.315-322. ISSN 1220-1766.

57. THORSTEINSSON, G., G. GUNNARSDOTTIR, A. NICULESCU, Assessing the Value of a Mobile Application in Fostering Ideation within a School Context, Studies in Informatics and Control, ISSN 1220-1766, vol. 24(1), 2015, pp. 119-126.

58. GARCIA-MARTINEZ, S., Using Commercial Games to Support Teaching in Higher Education. Unpublished thesis. Montreal: University of Montreal, 2012.

59. WALKER, E., Exploring the Ancient, Virtual World: Engagement and Enrichment Within a Virtual Historical Learning Environment, 2012 (available at 2016 from http://faculty.rmu.edu/ short/ research/minecraft-ct/references/Walker-E2012.pdf accessed on 25.06.2016)

60. WERBACH, K., D. HUNTER, For the Win: How Game Thinking Can Revolutionize Your Business. Philadelphia, PA: Wharton Digital Press, 2012.

61. WITFELT, C., Educational Multimedia and Teachers' Needs for New Competencies to Use Educational Multimedia. Education Media Intl., vol. 379(4), 2000, pp. 235-241.

62. WORTHINGTON, T., Blended Learning: Using a Learning Management System Live in the Classroom. The Australian National University, 2008.

63. ZICHERMANN, G., Fun is the Future: Mastering Gamification, Google Tech Talk October 26, 2010, (available at http://www.youtube.com/watch? $\mathrm{v}=6 \mathrm{O} 1 \mathrm{gNVeaE} 4 \mathrm{~g} \&$ feature $=$ player_embedd ed accessed on 25.01.2016). 